\title{
Exemplary Deterrent or Theatre of Martyrdom?: John Ogilvie's Execution and the Community of Glasgow
}

\author{
Paul Goatman \\ University of Glasgow \\ p.goatman.1@research.gla.ac.uk
}

\begin{abstract}
John Ogilvie's martyrdom in February 1615 should be seen in the context of a struggle for the hearts and minds of the people of Scotland between the Jesuit mission and James VI and I's government. Nowhere was this struggle more intense than within the town of Glasgow, where Ogilvie was imprisoned, tried and executed and which a large and influential Catholic community had long called home. Propaganda was disseminated by both sides during and after his trial and the archbishop of Glasgow, John Spottiswood, orchestrated its proceedings as a demonstration of royal and archiepiscopal power that involved local elites as well as central government officials. This article examines the events that took place in Glasgow during the winter of $1614^{-15}$ and provides a prosopographical analysis of the people involved. It makes the argument that, as had been the case during the Protestant Reformation of the 1540 s and 1550s, Scotland's church and state mishandled Ogilvie's public ritual execution such that the local religious minority (now Catholics) became emboldened and more committed to Counter-Reformation.
\end{abstract}

\section{Keywords}

John Ogilvie - King James VI and I - Archbishop John Spottiswood - Glasgow martyrdom - public ritual execution - propaganda - Counter-Reformation - state formation 
John Ogilvie's (1579-1615) trial and execution await a modern study. The contributions in the present issue provide rich context for the events that took place in Glasgow during the autumn and winter of 1614-15, and outline the complex political, intellectual and theological landscape within which Ogilvie's mission and execution should be located. They also highlight some of the long-term legacies for Scotland that were put in train by the Jesuit missions of the sixteenth and early seventeenth centuries. The aim of this article is to explore a different and under-explored dimension of Ogilvie's mission: his trial and execution as a contested political act. Both the state, represented by the archbishop of Glasgow, John Spottiswood (1565-1639), and Ogilvie himself competed for their respective versions of events to take precedence in the public consciousness. Here, particular focus is placed on the impact that the execution had upon the local community of Glasgow; an aspect of his trial that has been overlooked by historians.

As was argued in the introduction to this issue, important context for such a discussion has been provided by the recent work of Daniel MacLeod. His focus on the propaganda war that followed the trial demonstrates the extent to which Ogilvie's execution generated controversy within Scotland. ${ }^{1}$ Further context is provided by recent work on the nature of capital punishment in early modern Europe, which has pointed to a dissonance between the ways that the penalty was understood "from above," by governments and church authorities, and "from below," by ordinary people. Paul Friedland has suggested that in France by the sixteenth century, the practice of the execution ritual had evolved over many hundreds of years and was generally interpreted by witnesses as an act of public penance and understood in terms of Christ's passion. An execution could also serve several purposes for a community. It of course permanently removed the offender; it also expunged the crime and allowed the local corpus christianum to heal as a result of experiencing the performance of the killing itself. ${ }^{2}$ This interpretation has particular resonance in an early modern

1 Daniel MacLeod, "Declining His Majesty's Authority: Treason Revisited in the Case of John Ogilvie," in Scotland's Long Reformation: New Perspectives on Scottish Religion, c.1500-c.166o, ed. John McCallum (Leiden: Brill, 2016), 179-201.

2 Paul Friedland, "Beyond Deterrence: Cadavers, Effigies, Animals and the Logic of Executions in Pre-modern France," Historical Reflections / Réflexions Historiques, 29, no. 2, Interpreting the Death Penalty: Spectacles and Debates (2003): 295-317, at 313-14; Paul Friedland, Seeing Justice Done: The Age of Spectacular Capital Punishment in France (Oxford: Oxford University Press, 2012), 110, 116. 
Scottish context thanks to the work of Margo Todd, who has shown that by the early seventeenth century, communities were familiar with the practice of performative public penance and the meanings that lay behind it. She has argued that the ministers, presbyteries and kirk sessions of post-Reformation (Lowland) Scotland made extensive use of the performance of discipline in order to cultivate a "culture of Protestantism" amongst the laity. ${ }^{3}$ Although by 1615 the people of Glasgow were familiar with the performative aspects of secular justice and religious penance, executions were rare in Reformation-era Scotland and Ogilvie was the first Catholic to be put to death there after the Reformation Parliament of $1560 .{ }^{4}$ The novelty of the event should therefore be taken into account when trying to gauge its impact upon witnesses. Friedland's work also shows that by the sixteenth century, the theory of capital punishment as an exemplary deterrent, which could be used to terrify onlookers into obedience before the state, had evolved from Roman legal theory, but separately from the customary practice of the ritual itself. ${ }^{5}$ It seems possible therefore to point to a potential disconnect between what James VI and I (1566-1625; r. [Scotland] 1567-1625 [England] 1603-25) and Archbishop Spottiswood thought they could achieve by putting Ogilvie to death in February 1615 and the ways in which the people of Glasgow interpreted the execution.

A complicating factor was that historically, neither church nor state in Scotland had ever been particularly successful in exercising their authority in this way through set-piece ritual executions. Jane Dawson, in her study of Scotland's "theatre of martyrdom" prior to 1560 , argued that the church was ineffectual when it came to convincing watching crowds that the Protestant heresy needed to be expunged from the kingdom. Indeed, she contended that through its frequent mismanagement of these spectacles, the Catholic Church achieved the precise opposite of what was intended, allowing the accused to "steal the show" and the crowds to "hijack" the proceedings and impose their own interpretation upon the often gruesome events that they witnessed. This strengthened popular support for Protestantism and was a contributing factor in the church losing control of religious politics in Scotland by $1558 .{ }^{6}$ Ritual

3 Margo Todd, The Culture of Protestantism in Early Modern Scotland (London: Yale University Press, 2002).

4 David Calderwood, The History of the Kirk of Scotland, ed. Thomas Thomson, 8 vols. (Edinburgh: Wodrow Society, 1842-49), 7:196.

5 Friedland, Seeing Justice Done, 116.

6 Jane Dawson, "The Scottish Reformation and the Theatre of Martyrdom," in Martyrs \& Martyrologies: Studies in Church History, ed. Diana Wood (Oxford: Blackwell, 1993): 259-70, quotations at 270 . 
executions were therefore high-stakes gambles that mixed performance and politics, which could often go badly wrong. A supposed eye-witness account of John Ogilvie's execution, which reported that the Jesuit did not die immediately when the ladder supporting his weight was removed, and that the hangman therefore had to pull at his feet from below in order to break his neck, suggests that by the second decade of the seventeenth century the Scottish episcopate was similarly inept when it came to using executions to enforce religious conformity. ${ }^{7}$ Yet, Ogilvie's trial and public execution did indeed involve an attempt (however incompetent) by the government to create and manage a "theatre of death" in Glasgow, to convince local Scots of the treasonous nature of Catholicism, the power of the newly re-instated episcopate and the authority of the crown.

The question of whether Ogilvie or the state ultimately won the propaganda war lies at the heart of this article. Did Ogilvie's execution act as an "exemplary deterrent" for those who witnessed it, or did the town become a "theatre of martyrdom," which served only to strengthen the faith of local Catholics? In an attempt to answer this question, this article provides a prosopographical analysis of Glasgow's Catholic community in 1614-15. In the process, it builds upon John Durkan's 1970 study of "John Ogilvie's Glasgow associates," the local men and women who supported the Jesuit during his mission. It argues that they constituted the cream of elite Glasgow society, who occupied the highest echelons of political power in the burgh, and that John Spottiswood's decision to hold the trial in Glasgow was made with them firmly in mind. Spottiswood used Ogilvie's trial in an attempt to demonstrate archiepiscopal authority in a town previously tolerant of Catholicism, which also happened to be the largest urban centre within his demesne. Durkan divided Ogilvie's "Glasgow associates" into two categories. The first comprised those who actively helped him during his mission and were called upon to testify at his trial, while the second included men and women who, if not Catholic themselves, appear to have been tolerant of Catholics both before and after February 1615. This second group included influential figures such as the magistrates of the town's burgh court. They were responsible for sentencing Ogilvie, which raises the intriguing prospect that he may have been condemned to death by Catholic judges, or at least by men who had previously been sympathetic to Catholicism. ${ }^{8}$ Durkan's categorisations open up a series of questions around what King James and John Spottiswood thought they were achieving by publicly executing Ogilvie.

7 William E. Brown, John Ogilvie: An Account of His Life and Death with a Translation of the Documents Relating Thereto (London: Burns Oates \& Washbourne, 1925), 145, 279, 303.

8 John Durkan, "Miscellany," Innes Review 21, no. 2 (1970): 153-70, at 153-56. 
The crown tried to show Glasgow's ruling elite, in no uncertain terms, that Catholicism was the same as treason. At the same time, the state attempted to draw the town's most senior officials into the process of sentencing, in order to test their allegiance to the crown. The community of Glasgow was also on trial.

\section{Glasgow's Catholic Community}

Durkan's list of "John Ogilvie's Glasgow associates" reads as a "who's-who" of the most prominent political figures in the burgh during the first two decades of the seventeenth century. This group has been described elsewhere as "a Catholic congregation amongst the bourgeoisie of Glasgow." ${ }^{\text {The town it- }}$ self was home to around eight thousand adults at the time of Ogilvie's mission. Glasgow was therefore still relatively small in this period-estimates have placed its population at 7,644 in 1610 for example, compared to 25,000 in contemporary Edinburgh — and Catholics were influential amongst its political elite. ${ }^{10}$ In order to pinpoint who Ogilvie's supporters were, it is helpful to first recount his movements in the town during his initial visit in the autumn of 1614 , and the meetings that he had at that time. Much of this information is provided by Spottiswood's account of testimonies given at the trial, which can be found in his A True Relation, encompassed in Robert Pitcairn's Ancient Criminal Trials in Scotland, and in letters sent by the archbishop from Glasgow to the king in London during October $1614 .{ }^{11}$ These sources represent the government's version of events and their bias should be borne in mind, but they are likely to provide an accurate, if limited, account of Ogilvie's movements as they contain only the information that the accused parties were happy to offer up to the authorities. The depositions that they presented to Spottiswood in October 1614 describe how the priest first met with Robert Hegate, who was his main point of contact and most ardent supporter in Glasgow, and would later be described by Spottiswood as "the seducer of the rest" [of Ogilvie's supporters]. ${ }^{12}$ He then passed to the house of Mr. William Stewart, where the two men picked

9 Brown, John Ogilvie, $5^{2}$.

10 Third Statistical Account of Scotland: City of Glasgow, ed. James Cunnison and J. B. S. Gilfillan (Glasgow: Collins, 1958), 58; James McGrath, "The Medieval and Early Modern Burgh," in Glasgow: Volume 1, Beginnings to 1830, ed. Tom Devine and Gordon Jackson (Manchester: Manchester University Press, 1995), 17-62, at 45.

11 Robert Pitcairn, Ancient Criminal Trials in Scotland, 3 vols. (Edinburgh: Bannatyne Club, 1833), 3/1:330-54; Original Letters Relating to the Ecclesiastical Affairs of Scotland, 16o31625, ed. Beriah Botfield, 2 vols. (Edinburgh: Bannatyne Club, 1851) [oLEAS ], 2:387-91. 
up a chopine [half-pint] of wine before going on to Marion Walker's house where Ogilvie led a Mass. ${ }^{13}$ Walker has become an almost folkloric Glasgow figure because of the role that she played in Ogilvie's martyrdom. She seems to have been a devout Catholic for many years prior to 1615 . She had frequently been called before the Glasgow presbytery during the 1590s and at an appearance there in 1604 defiantly stated "that there is ane crucifix in ane bred in her house and $[. .$.$] that she should have more of them gif she had silver." { }^{\prime 14}$ Her son, Archibald Mure, also figured prominently amongst Ogilvie's supporters..$^{15}$ According to some accounts, Marion Walker was imprisoned because of her associations with Ogilvie, and died in jail in Glasgow during early $1615 \cdot{ }^{16}$

Also present with Ogilvie in Marion Walker's house were William Menteith, Matthew Adam, Thomas Forrett and James Forrett. Two days later, Ogilvie led a second Mass in Walker's house. Robert Hegate would later confess at his deposition that he also said Mass a third time, in his house. That Ogilvie said three Masses was verified by William Mentieth, who admitted to being present at all of them. Thomas Forrett also acknowledged that he had attended a Mass, although he claimed that he did so only on one occasion and that he had not attended one since then, because "seeing be the sight thereof he despysit that religion [Catholicism]." ${ }^{\prime 7}$ In his own deposition, the merchant Matthew Adam admitted to converting to Catholicism five years previously while on a business trip to Danzig but claimed that he was now a practicing Protestant. John Wallace of Corsflat and Mr. John Mayne, a future Benedictine priest, also admitted that they had attended the Mass. James Stewart of Flock was another man present at some of Ogilvie's meetings. He was also called upon to testify before Spottiswood and declared that Robert Hegate had brought Ogilvie to his house, where the three of them had shared some of the wine. He then accompanied them to Marion Walker's house and engaged in debates with Ogilvie about religion in her yard, although he "would na wayis yield to him." Stewart claimed that he then left the two men and did not go on to participate in any of the Masses. ${ }^{18}$ As might be expected in the course of a criminal trial, there

13 Pitcairn, Ancient Criminal Trials, 3/1:352; OLEAS, 2:387-88.

14 Glasgow City Archives [GCA], Glasgow presbytery records, 1592-1599, $\mathrm{CH}_{2} / 171 / 32 / 211-12$; $\mathrm{CH} 2 / 171 / 33 / 122-23$; Daniel MacLeod, "Servants to St Mungo: The Church in SixteenthCentury Glasgow" (PhD diss., University of Guelph, 2013), 195-98; GCA, Glasgow presbytery records, $1603-8, \mathrm{CH} 2 / 171 / 1 / 3 / 267$ for quotation.

15 Durkan, "Miscellany," 155.

16 Brown, John Ogilvie, 53, cf. MacLeod, "Servants to St Mungo," 197.

17 Pitcairn, Ancient Criminal Trials, 3/1:354.

18 Pitcairn, Ancient Criminal Trials, 3/1:353. 
was a significant amount of dissembling by those accused of associating with Ogilvie, as they sought to downplay their involvement with him.

Ogilvie's later beatification hearings, which took place during 1628 and 1629 in Rome and Würzburg, offer a different perspective on his activities in Glasgow. Three eyewitnesses to his trial in 1614-15 were called upon by the Catholic authorities to give evidence in support of his elevation. At Rome, an Edinburgh-based advocate, Mr. William Sinclair, testified that fifteen men had been imprisoned with Ogilvie in Glasgow between October 14, 1614 and March 10, 1615, including Archibald Mure, John Mayne, James Forrett, John Wallace, Matthew Adam, James Stewart and Robert Hegate. ${ }^{19}$ At Würzburg, James Hegate (Robert's brother), who had by then become a Benedictine monk, testified that fourteen men had been imprisoned with Ogilvie. ${ }^{20} \mathrm{He}$ also produced cherished letters, signed by Ogilvie, which the latter had given to him during his period of imprisonment in Glasgow. ${ }^{21}$ A second Glasgow-born Benedictine, John Mayne, had also been one of Ogilvie's associates in 1614-15 and was called upon to give evidence in Würtzburg. He corroborated the list of names that had been presented by James Hegate, adding those of Thomas Forrett, Andrew Schomer, Archibald Schilk, William Menteith and Marion Walker. He also mentioned that Andrew Boyd, who is well-known to historians as the man who betrayed Ogilvie to Spottiswood, had heard one of the Masses that he gave and had also subsequently been imprisoned. ${ }^{22}$

According to all of these testimonies-both those given by the townspeople accused of associating with Ogilvie during the autumn of 1614 and by the priests who gave evidence at his later beatification hearings - the group that supported him in Glasgow seems to have numbered at least fifteen people. The same names appear repeatedly throughout the various testimonies and despite the attempts made by some of the accused to mislead Spottiswood and the other interrogators, a majority of this group do seem to have been committed Catholics, and to have attended Mass at least once with Ogilvie. It is also clear that many of this group were prominent members of Glasgow's town council and magistracy. James Stewart of Flock, for example, had been the provost [chief magistrate] of the burgh as recently as 1613-14 and would hold the position again in 1617 and $1618 .{ }^{23} \mathrm{He}$ also served as a bailie [magistrate] of

\footnotetext{
19 Brown, John Ogilvie, 274.

20 Brown, John Ogilvie, 302.

21 Brown, John Ogilvie, 301.

22 Brown, John Ogilvie, 297.

23 John Anderson, The Provosts of Glasgow from 1609 to 1833, ed., James Gourlay (Glasgow: J. Hedderwick, 1942), 5 .
} 
the burgh court for six years between 1588 and 1613 and as a town councillor for four years. ${ }^{24}$ An Archibald Mure had been a town councillor during the year 1599-160o. ${ }^{25}$ James Forrett was a bailie for one year and a town councillor for six between 1600 and $1607 .{ }^{26} \mathrm{He}$ was also Glasgow's most frequent commissioner to parliament, conventions of estates and the Convention of Royal Burghs during those years, and was therefore active in representative assemblies at the national level. ${ }^{27}$ At the end of the sixteenth century and the beginning of the seventeenth, Glasgow was governed by an oligarchic ruling elite. James McGrath has shown, for example, that just twenty-four men dominated the town council and magistracy between 1574 and $1586 .{ }^{28}$ Many of John Ogilvie's Catholic supporters were part of this influential and select group.

John Durkan's work has also identified a second category of men and women associated with Ogilvie, whose religious beliefs are more difficult to discern. Members of this group were also prominent within the magistracy. James Hamilton, for example, was the provost of Glasgow in 1615 and oversaw Ogilvie's trial. He was married to Elizabeth Adam, a relative of the Catholic merchant Matthew Adam. ${ }^{29}$ The three Glasgow bailies who also adjudicated at the trial were James Bell, James Braidwood and Colin Campbell. Campbell was the father of a Robert Campbell, who would later go on to appear before the Glasgow presbytery charged with importing items for use in the Mass and presenting them to James Stewart, the son of James Stewart of Flock. ${ }^{30}$ Durkan seemed to infer that there was at least a degree of religious tolerance to be found amongst the magistrates who, if they were not Catholics themselves, tolerated them and were happy for their wives and children to practice the religion. That they were given the responsibility of sentencing Ogilvie to death in February 1615 is perhaps a case of the crown and Spottiswood using his trial to

24 GCA, Glasgow town council minutes, $\mathrm{Cl} / 1 / 3$, f. 1; $\mathrm{Cl} / 1 / 4$, fols. 1, 73, 129; $\mathrm{C} 1 / 1 / 5$, fols. 48-50, 103-4, 157; C1/1/6, fols. 21-22, 114-15, 155, 236; C1/1/7, fols. 1, 13, 53, 98.

$25 \mathrm{GCA}, \mathrm{Cl} / 1 / 5$, fol. 50.

26 GCA, C1/1/5, fols. 103-4, 157; C1/1/6, fols. 21-22, 114-15.

27 Records of the Convention of the Royal Burghs of Scotland, ed. James Marwick and Thomas Hunter, 7 vols. [RCRBS] (Edinburgh, 1866-1918), 2:92, 107-8, 147, 183-84; Margaret Young, The Parliaments of Scotland: Burgh and Shire Commissioners, 2 vols. (Edinburgh: Scottish Academic Press, 1993); The Records of the Parliaments of Scotland to 1707, ed. Keith Brown et al. (St Andrews: University of St Andrews, 2007-20).

28 James McGrath, "The Administration of the Burgh of Glasgow, 1574-1586," 2 vols. (PhD diss., University of Glasgow, 1986), 1:56-79.

29 Anderson and Gourlay, Provosts, 7; Durkan, "Miscellany," 156.

30 Durkan, "Miscellany," $155^{-56}$ and see below. 
force them to choose between allegiance to the king and their previous adherence to religious pluralism. The former was surely the easier choice.

Durkan also noted the close links that existed between these "associates" of Ogilvie and a recusant Catholic notary and town clerk of Glasgow named Archibald Hegate, who lived and practiced his profession in the burgh between the 1570 s and 1612. ${ }^{31}$ The Robert and James Hegate mentioned above were his sons. ${ }^{32}$ Archibald was a prominent figure in the town, with close links to Esmé (1542-83) and Ludovick Stewart (1574-1624), the first and second dukes of Lennox. ${ }^{33}$ It has recently been argued that Archibald was a devout Catholic throughout his life, who adopted a Nicodemite strategy of dissembling before the kirk in Glasgow and may even have had a direct hand in the organisation of Ogilvie's mission. ${ }^{34}$ It has also been suggested that his attitude toward the kirk was determined more by royal policy than the endeavours of the town's Protestant ministers. On the occasions that James vi persecuted Catholics, Hegate sought reconciliation with the kirk; at most other times he could get away with being openly defiant because of the king's tolerant attitude. ${ }^{35}$ This was because the town's magistrates responded to the orders of the king before those of the clergy. James vi was generally tolerant of Catholics, unless it suited him not to be, which was usually the case only for short-term political reasons. ${ }^{36}$ Between the 1580 s (when church records for Glasgow first become extant) and the return of an episcopate with fully-restored powers via the 1610 General Assembly and 1612 parliament, the attitude of the secular authorities toward Catholics in Glasgow is best described as one of de facto religious tolerance. After the latter date, hardening attitudes both from the archbishops (with royal backing) and the Society of Jesus sought to eradicate religious pluralism in Scotland. ${ }^{37}$ This was the point at which Archibald Hegate left Glasgow, near the end of 1612, and travelled to Rome, where he received a pension from the pope. ${ }^{38}$ This date also

\footnotetext{
31 Durkan, "Miscellany," 153.

32 Durkan, "Miscellany," 153.

33 Paul Goatman, "Religious Tolerance and Intolerance in Jacobean Scotland: The Case of Archibald Hegate Revisited," Innes Review 67, no. 2 (2016): 159-81, at 164-65.

34 Goatman, "Religious Tolerance," 171-80.

35 Goatman, "Religious Tolerance," 170-76, 180-81.

36 Goatman, "Religious Tolerance," $160-61$, where some of the historiography relating to James vi's religious tolerance is noted.

37 R. Scott Spurlock, "Scottish Catholicism in the age of John Ogilvie," unpublished paper given at the Glasgow meeting of the Newman Society (2015); Allan Macinnes, "Catholic Recusancy and the Penal Laws, 1603-1707," Records of the Scottish Church History Society 23 (1989): 27-63, at 38-40; Goatman, "Religious Tolerance," 159, 181.

38 Brown, John Ogilvie, 284; Goatman, "Religious Tolerance," 164.
} 
coincided with the beginning of the preparatory stage of John Ogilvie's mission, which was mostly organized in Bordeaux. ${ }^{39}$ Archibald Hegate may have been involved in the planning of the mission at that time. ${ }^{40}$

The survival of Catholics in Glasgow at the head of the town council and magistracy, fifty-five years after the Reformation Parliament of 1560, and the prevailing attitude of religious tolerance amongst those same civic leaders, can perhaps be explained by the burgh's political relationship with the crown during James VI's reign. Historians of Reformation Scotland have recently been reminded of the "tradition of intolerance" in the Scottish Kirk and that religious tolerance in this era was a "loser's creed," "the party cry of the disappointed, the dispossessed or the seriously confused." ${ }^{41}$ The religious tolerance that endured in Glasgow prior to the re-establishment of the episcopate may have been the result of such weakness - on the part of the kirk, the burgh magistrates and even the crown-but it meant that a close-knit Catholic community was able to survive in the town between the 1560 parliament and John Ogilvie's mission in 1614-15. Indeed, there is evidence that Catholics continued to live in the burgh throughout the remainder of James's reign and that of his son, Charles (1600-49; r.1625-49). This will be addressed below. Glasgow's status as an ecclesiastical burgh and its close relationship with the crown after the Reformation and the flight of the last Catholic archbishop, James Beaton (II) (1524-1603), to France during 1560 helped to create an environment that was conducive to the survival of Catholicism. Archibald Hegate and his father William, for example, maintained contact with Beaton until his death in 16o3. They seem to have remained loyal to him during this period and surely hoped that he would one day return to Scotland. ${ }^{42}$ Catholic survival in Glasgow was also aided by

39 Brown, John Ogilvie, 25-26.

40 Goatman, "Religious Tolerance," 176-80.

41 R. Scott Spurlock, "The Tradition of Intolerance in the Church of Scotland," in Reformed Majorities in Early Modern Europe, ed. Herman Selderhuis and J. Marius J. Lange van Ravenswaay (Göttingen: Vandenhoeck \& Ruprecht, 2015), 295-311; Roger Mason, "Divided by a Common Faith?: Protestantism and Union in Post-Reformation Britain," in McCallum, Scotland's Long Reformation, 203, where Mason quotes from Andrew Pettegree, "The Politics of Toleration in the Free Netherlands, 1572-1620," in Tolerance and Intolerance in the European Reformation, ed. Ole Peter Grell and Robert Scribner (Cambridge: Cambridge University Press, 1996), 182-98.

42 "Excerpt from Letter by Queen Mary to the Archbishop of Glasgow, dated 20 January, 1566-7," in Abstracts of the Protocols of the Town Clerks of Glasgow, ed. Robert Renwick, 11 vols. (Glasgow, 1894-1900) [Glasgow Protocols], 4:124-25; Miscellaneous Papers, Principally Illustrative of Events in the Reigns of Queen Mary and King James VI, ed. William Duncan (Glasgow: Maitland Club, 1834), 43-44, cf. Robert Renwick, "The Archiepiscopal 
the various constitutional settlements adopted by the crown in relation to the burgh during James' reign, as well as the general inconsistency and tolerance of the king in matters of religion. During $1586-87$ for instance, James entertained the idea of restoring Beaton to the temporalities of his archiepiscopal see, before deciding instead to annex the kirk's entire ecclesiastical benefices to the crown in July 1587 , which brought the burgh of Glasgow within the royal demesne for the first time. ${ }^{43} \mathrm{He}$ then used these lands to reward his most loyal courtiers, appointing them as the feudal superiors of the burgh. The king transferred the archiepiscopal patrimony first to his treasurer, Walter Stewart, the lay commendator of Blantyre (d.1617), in November 1587 and then Ludovick Stewart, the second duke of Lennox, in June $1593 \cdot{ }^{44}$ In September 160o, the king changed his policy toward Glasgow again, installing another favoured courtier and someone he hoped would modernise the burgh's civic administration, Sir George Elphinstone of Blythswood, as the town's provost. ${ }^{45}$ While Walter Stewart seems to have been a Protestant and a staunch supporter of the kirk, Lennox's own religious beliefs are harder to pin down. The kirk certainly suspected that he was a Catholic. ${ }^{46}$ Sir George Elphinstone may also have been a Catholic, like other members of his family. In 1599, his close relationship with the king was a concern for English agents at the royal court, probably for this reason. ${ }^{47} \mathrm{He}$ was certainly a close associate of Archibald Hegate, and employed him in his capacity as a notary and reinstated him to the position of town

Temporalities of Glasgow," in Regality Club, vol. 4 (Glasgow: James Maclehose and Sons, 1900), 153 .

43 Renwick, "Archiepiscopal Temporalities," 145-55.

44 "Act in favour of [Ludovic Stewart], Duke of Lennox regarding the superiority of the bishoprics of St Andrews and Glasgow," RPS, 1593/4/74; "Charter of James VI granting in feu the lands and barony of Glasgow to Walter, Commendator of Blantyre (1587)," in Marwick, Charters and Documents, 2:215-25.

45 Extracts from the Records of the Burgh of Glasgow 1573-1833, ed. James Marwick, 11 vols. (Glasgow: Scottish Burgh Records Society, 1876-1916), 1:213; William Fowler, A True Reportarie of the Baptisme of the Prince of Scotland (Edinburgh, 1594), 19.

46 For Stewart's support for the kirk, see GCA, Glasgow High Kirk session book, CH2/550/1, fol. 174; Also, Extracts from the Records of the Burgh of Edinburgh, 1573-1589, ed. James Marwick (Edinburgh: Scottish Burgh Records Society, 1892), 511-12; For the kirk's suspicions about Lennox, see Adrienne McLaughlin, "Rise of a Courtier: The Second Duke of Lennox and Strategies of Noble Power under James VI," in James VI and Noble Power in Scotland, 1578-1603, ed. Miles Kerr-Peterson and Steven J. Reid (Abingdon: Routledge, 2017), 139-40.

47 Calendar of the State Papers relating to Scotland and Mary, Queen of Scots, 1547-1603, ed. Joseph Bain, 13 vols. (Edinburgh: General Register House, 1898-) [CsP Scot.], 13:436, no. 347; 644, no. 513; Amy Juhala, "The Household and Court of King James vi of Scotland, 1573-1603" (PhD diss., University of Edinburgh, 2000), 67, 254. 
clerk of Glasgow in $1604{ }^{48}$ The Catholic Forrett family were also supporters of Elphinstone's. ${ }^{49}$ The king's own religious tolerance and the changing feudal superiority of the burgh of Glasgow between 1586 and 1603 therefore helped to create a political environment in the locality that allowed Catholics to thrive after the Reformation and permitted them access to the town's highest political offices. Many of them supported John Ogilvie during 1614-15.

Amongst those historians who have examined Ogilvie's trial, there is a prevailing consensus that Spottiswood and the king did not initially intend to execute Ogilvie, and that his death should therefore be seen as somewhat of an accident. It has nevertheless long been understood that the period which followed the return of the archbishops to the full extent of their powers at the 1612 parliament was one in which Catholics faced high levels of persecution. Professor Allan Macinnes, for example, has described the period between 1612 and 1616 as "a markedly vindictive phase in the prosecution of Catholic clergy." ${ }^{0}$ Alan MacDonald has summarised the generally-accepted view of Ogilvie's execution, noting that the king did not want to have him killed and "was inclined to have him banished as long as he did not assert the supreme authority of the Pope. ${ }^{51}$ When Spottiswood questioned Ogilvie, it was in the hope that he would acknowledge the royal supremacy, and it was Ogilvie's refusal to do so that led to his execution. Even during the "vindictive phase" after 1612, other Catholic clergy were not put to death. ${ }^{52}$ At the same time that Ogilvie was apprehended in October 1614, another Jesuit, Robert Moffat, was arrested in St Andrews by the archbishop there, George Gledstanes (c.1562-1615). Under interrogation, Moffat acknowledged the royal supremacy in matters of religion and his life was spared. MacDonald has suggested that the archbishops did not intend that Ogilvie should be martyred, rather that the dual arrest would result in both priests publicly recognising the supremacy of the crown, and thus also

48 Renwick, Glasgow Protocols, x, 62-65, 69, 71-74, 78-80; Goatman, "Religious Tolerance," $175^{-76 .}$

49 The Register of the Privy Council of Scotland. First series, ed. John Burton et al., 14 vols. (Edinburgh: General Register House, 1877-) [RPC, first ser.], 7:247.

50 Macinnes, "Catholic Recusancy," 40.

51 Alan MacDonald, The Jacobean Kirk, 1567-1625: Sovereignty, Polity and Liturgy (Farnham: Ashgate, 1998), 155 .

52 MacDonald, Jacobean Kirk, 155 . 
the prelates' authority. ${ }^{53}$ Daniel MacLeod has also drawn attention to the accidental nature of Ogilvie's execution, this time from the priest's own perspective, by examining his unwavering desire to pursue martyrdom. This "was not as easy as it would seem in Scotland, where executions on religious grounds were relatively rare in the Reformation period." ${ }^{54}$ MacLeod has highlighted several instances recounted by Ogilvie in his Relatio, in which he claimed that Spottiswood provided him with opportunities to avoid execution. In the Relatio, Ogilvie tried to create a narrative in which he worked steadfastly toward his own martyrdom, in the face of the archbishop's attempts to divert him from this course by keeping him alive. ${ }^{55}$ His own version of events reinforces the idea that Spottiswood did not at first want to have him killed, which provides further evidence that Ogilvie's was an "accidental" execution.

However, it also seems that Spottiswood used the opportunity provided by Ogilvie's arrest to present a united government front in Glasgow and make a show of royal and archiepiscopal strength in the burgh. The Privy Council initially ordered that the trial be held in Edinburgh, but Spottiswood petitioned the king to have it transferred to Glasgow so that he could maintain greater control over proceedings. ${ }^{56}$ In November 1614, the archbishop also revealed another reason for staging the trial in Glasgow. He wrote to John Murray of Lochmarben (d.1640), a gentleman of the king's bedchamber responsible for handling royal correspondence, stating:

The course of Papistrie has gone on so far here, by the negligence of our Ministers, the foolishness of some of ourselves that his Majesty has placed to hold them to their duties, and the favour born to them by sum principal of our state, that I assure you nothing keeps religion here but his Majesty's countenance and favour to it. ${ }^{57}$

Spottiswood added that he had received intelligence of twenty-seven Jesuits in the kingdom, "two depute for every diocese; and one Father Bel, the Pope's Legate, that directs them, and takes account quarterly of their success and

\footnotetext{
53 MacDonald, Jacobean Kirk, 155.

54 MacLeod, “Declining his Majesty's Authority," 188.

55 MacLeod, "Declining his Majesty's Authority," 188.

56 OLEAS, 2:399-400. This interpretation is given by A. S. Wayne Pearce, in "John Spottiswoode, Jacobean Archbishop and Statesman" (PhD diss., University of Stirling, 1998), at 127 .

OLEAS, 2:400.
} 
how they speed." 58 While surely an exaggeration, this seems to provide further evidence for MacDonald's argument that Spottiswood intended to use Ogilvie's interrogation to reinforce archiepiscopal supremacy over religious affairs in Scotland. The evidence presented earlier in this article also suggests that Spottiswood may equally have had Glasgow in mind when he wrote this letter, and decided to move the trial there in order to make a statement about the treasonous nature of Catholicism directly to the people of the town. David Calderwood (c.1575-1650), writing after the execution, ascribed similar political motivations to Spottiswood, but emphasised that the archbishop wanted to use the trial to strike fear into dissenting Presbyterian ministers rather than Catholics. He commented that

Some interpreted this execution to have proceeded rather of a care to bless the king's government, than of any sincere hatred of the Popish religion. Some deemed that it was done to be a terror to the sincerer sort of the ministry, not to decline the king's authority in any cause whatsoever. ${ }^{59}$

Further evidence that John Spottiswood had the community of Glasgow in mind during Ogilvie's trial is provided by the lists of personnel that he appointed as judge and jury. An initial justice commission granted by the king and recorded by the Privy Council in November 1614 only included Spottiswood, Sir Gideon Murray of Elibank (c.1560-1621), the treasurer deputy of Scotland, Sir Alexander Hay of Whiteburgh, the clerk of register, and Sir William Livingstone of Kilsyth (d.1626/27), a Stirlingshire laird and one of the senators of the College of Justice. ${ }^{60}$ Any three of them would suffice in the role, so long as the Archbishop of Glasgow was always present. The royal order also stipulated that the commission should "call before them such persons within the said city suspect guilty of the reset of the said priest and of the hearing of his mass" and set up a court of justiciary within the Glasgow tolbooth. ${ }^{61}$ No mention was made of the town's provost and bailies, although it was perhaps presumed that they would oversee the trial as they were already the king's magistrates in the burgh.

At the beginning of the trial, on October 5, 1614, Spottiswood recruited Andrew Boyd, the bishop of Argyll (1567-1636), Sir Walter Stewart of Minto and Livingstone of Kilsyth to hear the suspects' testimonies. The last two were Protestant lairds with estates and large networks of local support based in the

\footnotetext{
58 OLEAS, 2:400.

59 Calderwood, History, 7:196.

6o $R P C$, first ser., 10:285.

$61 \quad R P C$, first ser., 10:285.
} 
rural hinterland around Glasgow. Also present were Sir George Elphinstone of Blythswood, James Hamilton, the town's provost, and the three bailies, James Bell, James Braidwood and Colin Campbell. ${ }^{62}$ Elphinstone's religious beliefs and those of the magistrates have been speculated upon above, while Minto and Kilsyth were staunchly Protestant. By this stage, no mention was being made of Murray of Elibank or Hay, the central government officials, and the king's stipulation that three of his original commission be present at all times does not seem to have been adhered to. From the outset therefore, John Ogilvie's trial was a distinctly local affair. At the time of Ogilvie's arraignment and his transportation to the scaffold on February 28, 1615, the provost and bailies were again present, as were the members of the commission initially named by the Privy Council. Also in attendance were James Hamilton, the marquess of Hamilton (1589-1625), Robert Kerr, earl of Lothian (c.1574-1624), William Crichton, Lord Sanquhar (d.1642/43), John, Lord Fleming (c.1567-1619), Robert, Lord Boyd (1595-1628) and Sir Walter Stewart of Minto. ${ }^{63}$ Again, it appears that local landowners and government officials had been carefully selected to make a strong showing of state power and local support for the crown. It has recently been suggested that the presence of these men placed the burgh magistrates under pressure to tow the royal line. ${ }^{64}$ Part of their role must also have been to preserve order in the town on the day of the execution. Perhaps more difficult to explain is the presence of others chosen to witness Ogilvie's arraignment. The reason for Sir George Elphinstone of Blythswood's presence appears straightforward enough, as he was still a powerful figure in the local area and a loyal servant of the crown. But also in attendance were Hew Kennedy, the provost of Ayr, and a number of Ayr burgesses. ${ }^{65}$ It is difficult to speculate as to why their attendance may have been required.

What effect did Ogilvie's closely-managed trial and execution have upon Glasgow's Catholic community? In the absence of eyewitness testimony, good evidence is provided by the appearance of recusant Catholics in Glasgow's church records after 1615. That many of the same people who had supported Ogilvie remained within the burgh as a clandestine Catholic group is evidenced in particular by the trial of James Stewart younger of Flock, whose proceedings dominated the attention of the Glasgow presbytery between December 1618 and August 1620. This appears to have been the same man mentioned above as having met with Ogilvie during the winter of $1614^{-15}$ and who testified before

\footnotetext{
62 OLEAS, 2:387; Pitcairn, Ancient Criminal Trials, 3/1:352.

63 Pitcairn, Ancient Criminal Trials, 3/1:339; Goatman, "Religious Tolerance," 179.

64 Goatman, "Religious Tolerance," 179.

65 Pitcairn, Ancient Criminal Trials, 3/1:345.
} 
Spottiswood under suspicion of harbouring him. In October 1618, Stewart's father had been appointed as provost of Glasgow by Spottiswood's successor as archbishop, James Law $(c .1560-1632)$. The younger Stewart would go on to enjoy a successful career both within the burgh's civic administration and in the service of Ludovick Stewart, second duke of Lennox. ${ }^{66}$ Lennox would appoint him Deputy Admiral of Scotland and justiciary within the bounds of the River Clyde between 1619 and $1624 \cdot{ }^{67} \mathrm{He}$ would go on to become a provost of the burgh himself in the $1630{ }^{68}$ At one point during his trial, in November 1619, Stewart was absent, and his case suspended, "because he was busied in my Lord Duke his adois [affairs]." 69 The important standing within the burgh of both James Stewart younger of Flock and his father suggests that his trial was also an attempt to exert archiepiscopal authority. A degree of detail has been included in the account of the trial which follows below, in an attempt to reveal something of the power struggle between Stewart and Archbishop Law and the presbytery at that time.

Stewart first came to the attention of the presbytery on December 30, 1618, for celebrating Christmas Day five days previously with some friends and going "through the said citie [...] with sounding of ane trumpet, blowing of ane horn and dancing with drawn swords." ${ }^{70}$ During the course of his trial he was found to have received rosary beads, a wax agnus Dei (lamb of God), crucifixes and a letter from William Hegate, Archibald's brother, who was at that time a professor at the College of Guienne in Bordeaux. ${ }^{71}$ These had come to him via a Glasgow merchant, Robert Campbell, whose father, Colin, had been one of the magistrates at Ogilvie's trial. ${ }^{72}$ In the course of his own trial, Stewart was described by the presbytery as having been previously convicted for apostasy and for being "airt and pairt of John Ogilvie the Jesuit's treason." ${ }^{33}$ At that time, he had apparently promised to adhere to the kirk's teachings, and was found to be in breach of this oath in receiving the Catholic items. ${ }^{74}$

\footnotetext{
66 Anderson and Gourlay, Provosts of Glasgow, 5-6.

67 NRS, Lennox papers, GD220/1/G/2/2/7, "Commission by Ludovick, Duke of Lennox, High Admiral of Scotland, to James Stuart younger of Floock" (1619).

68 Anderson and Gourlay, Provosts of Glasgow, 14.

69 GCA, Transcript of Glasgow presbytery minutes, 1616-27, $\mathrm{CH} 2 / 171 / 36 / 160$.

$70 \mathrm{CH} 2 / 171 / 36 / 129$.

71 For William Hegate's career, see John Durkan, "A Post-Reformation Miscellany II," Innes Review 55, no. 1 (2004): 53-72, at 66-69.

$72 \mathrm{CH} 2 / 171 / 36 / 129,152$.

$73 \mathrm{CH} 2 / 171 / 36 / 189$.

$74 \mathrm{CH} 2 / 171 / 36 / 189$.
} 
The trial lasted for so long because Stewart fought his case. Following his period of absence in the duke's service, he was summoned by the presbytery to appear again in January 1620 and threatened with excommunication. Stewart adopted two strategies in fighting the case. He initially claimed that if he was being accused of treason, then this was a civil matter which did not fall within the presbytery's jurisdiction, but the presbytery responded that he was not accused of treason "or any other capital crime but for apostasy and defection from true religion" and that it would therefore proceed against him "neither civillie nor criminallie but modo ecclesiastico." ${ }^{75}$ Stewart then argued that Scottish merchants were permitted to "have traffic and handling with strangers of whatsoever religion in civil and common affairs without either taking notice of their religion or regarding the same." Speaking of the items he had received, he added: "The having of such toys nor giving thereof cannot be input as a crime, being things of their own nature indifferent."76 Here, Stewart made an argument for the "irrelevencie of the lybell"-in effect that receiving letters from Catholics or possessing beads, crucifixes, and agnus Deis was not in itself forbidden. To this, the presbytery responded:

The very receiving of these beads, crucifixes and agnus deis from $\mathrm{Mr}$ William Hegate ane notorious and profest papist be James Stewart, who has not onlie this long time bein suspect of papistrie but also convict as airt and pairt of John Ogilvie the Jesuit's treason, does give just cause of suspicion and offence to all that hears and knows that he has received the same. ${ }^{77}$

The presbytery added that:

William Hegate is not a seller of beads, but a regent in a college and James Stewart is not a buyer, and therefore it cannot be thought the quality of both the persons being considered that either the one could send them or the other receive and keip them but to ane superstitious and idolatrous end and use. ${ }^{78}$

\footnotetext{
$75 \mathrm{CH} 2 / 171 / 36 / 160-65$.

$76 \mathrm{CH} 2 / 171 / 36 / 176-78$.

$77 \mathrm{CH} 2 / 171 / 36 / 189-91$.

${ }_{7} \mathrm{CH} 2 / 171 / 36 / 189-91$.
} 
After coming to this decision, the presbytery rejected Stewart's case and Archbishop Law, together with the town's ministers, announced the first sentence of excommunication against him on March 8, $1620 .{ }^{79}$

On March 15, Stewart sought reconciliation with the kirk, possibly following his father's advice, and gave in a supplication confessing his crimes. However, this was also rejected by the presbytery and on March 19, Law pronounced a second sentence of excommunication. ${ }^{80}$ After another three days, Stewart offered a further supplication, claiming that: "I am ashamed of my grievous sin that I have deeply apprehended lyk as I feel daylie the wecht of the dreadful sentence lying so heavy upon my troubled and waking conscience." The presbytery does not seem to have responded to this and on May 10, Stewart offered a third supplication, but again the presbytery postponed its verdict, due this time to the absence of the archbishop. In July Stewart offered a fourth supplication, but this was found to be "generall and weill slender, not beiring the confession of his fault." A fifth supplication was presented in August, which was finally accepted by the presbytery and on August 16, Law absolved Stewart of his excommunication. ${ }^{81}$ It is difficult to account for Stewart's apparent volteface before the Glasgow presbytery but his eventual compliance may have been due to his father's influence and his own desire for a quiet life after a long trial.

During the last five years of James vi's reign, Catholics continued to appear regularly before the Glasgow presbytery. In 1620, while James Stewart's trial was ongoing, John Schellis and Matthew Adam, another of Ogilvie's earlier "associates," were called before the presbytery as "suspect in religion." 82 Between 1621 and 1626, Duncan Sempill, a ship's captain, was consistently called by the presbytery to subscribe to the Confession of Faith, but provided a series of excuses, including on one occasion that he was ill and in 1622 that "there were many things as he allegit in the Protestant Confession of Faith that he understood not well [and] craved one month to be further advised." ${ }^{83}$ It seems likely that he was a Catholic who was able to avoid the attentions of the presbytery during these years because he was often at sea. In December 1622, Dame Isobel Leslie refused to subscribe to the Confession of Faith or attend sermon,

\footnotetext{
$79 \mathrm{CH} 2 / 171 / 36 / 197$.

80 On March 15, James Stewart elder appeared before the presbytery to say that his son would confess to receiving a "buist" and to giving the agnus Dei to Colin Campbell. See $\mathrm{CH}_{2} / 171 / 36 / 196-67$.

$81 \mathrm{CH} 2 / 171 / 36 / 201-2,211-13,216-9,223-25,227-30$.

$82 \mathrm{CH} 2 / 171 / 36 / 168-69$.

$83 \mathrm{CH} 2 / 171 / 36 / 225^{-26}, 25^{8}, 282,294,324,349$, quotation at 282.
} 
and was suspected of Catholicism by the presbytery, ${ }^{84}$ while in May 1626 , the presbytery complained that Sir William Hamilton of Elistone had returned to Scotland from France, since when he had "not only professed and allowed himself to be of the Roman religion, but hath also at diverse times and in diverse instances reasoned openlie against the religion presentlie professed and established within the Kingdom of Scotland and has refused to hear the word and participate in the holy sacraments." ${ }^{85}$ All of these cases suggest that John Spottiswood's close management of Ogilvie's trial had done little to quell Catholicism in Glasgow. Allan Macinnes has shown that Catholic activity continued in the town during the reign of Charles I and argued that recusancy had become "entrenched" there by the $1630{ }^{86}$

\section{4}

\section{Conclusion}

The propaganda published by the Jesuits and John Spottiswood immediately following John Ogilvie's execution reflected the fact that his trial was a battle for the hearts and minds of the people of Scotland. This struggle was especially intense in Glasgow, where Spottiswood deliberately arranged for the trial to be held and which was home to a large and influential Catholic community. The question posed in the title to this article-whether the execution is better understood as an "exemplary deterrent" or a "theatre of martyrdom" —is in some senses a misnomer, because these two elements were always present in any ritual religious killing by the state in early modern Europe. In addition, neither phrase is a fair description of Ogilvie's trial because they suggest that someone was in control of events and the surviving evidence indicates that the eventual execution was planned neither by Spottiswood, the king nor the government. Equally, as the work of Dawson and Friedland has shown, the tradition of capital punishment being used effectively as a deterrent did not exist in Scotland, as it did in other European kingdoms, such as France, and if there was a precedent, it was that Scottish authorities were ineffectual in carrying out such executions. Nevertheless, posing the question has allowed us to explore in detail the events that took place in Glasgow between October 1614 and February 1615. This has revealed both that religious attitudes were becoming polarised in the town at the time, reflecting developments in Scotland as a whole, and that the re-establishment of the archbishop in Glasgow led to a period of increased

\footnotetext{
$84 \mathrm{CH} 2 / 171 / 36 / 284$.

$85 \mathrm{CH} 2 / 171 / 36 / 339$.

86 Macinnes, "Catholic Recusancy," 30.
} 
persecution for the town's Catholics. Spottiswood attempted to use John Ogilvie's trial and execution as a show of royal and archiepiscopal power in the local area. Evidence is slim for the impact that this had upon Glasgow's Catholic community, but Catholics remained members of the political elite in the town throughout the 1620s. Indeed, the very same "associates" of Ogilvie's who had supported him in 1614-15 continued to be influential and to pose a challenge to the authority of the archbishop and presbytery into the 163os. This suggests that the effect of the execution was not one of deterrence and, as Professor Macinnes has argued elsewhere in this issue, served only to strengthen Catholic resolve. 